\title{
Sleep disturbances in a Canadian population with asthma or chronic obstructive pulmonary disease (COPD)
}

\author{
A Des Cormiers ${ }^{*}$, LP Boulet \\ From AllerGen NCE Inc.'s Fifth Annual Research Conference: Innovation from Cell to Society \\ Québec City, QC, Canada. 7-9 February 2010
}

\section{Objective/purpose}

To compare the self-reported prevalence of sleep duration and quality in patients with asthma, chronic bronchitis (CB), or undefined COPD in the Canadian population.

\section{Methods}

This cross-sectional survey was done using the Public Use Microdata File Canadian Community Health Survey (CCHS) Questionnaire for Cycle 1.1 (2000-2001). Ninetyeight percent of the Canadian population was represented by a sample of 133,000 persons, aged 12 or older.

\section{Findings}

A higher frequency of difficulty falling or staying asleep most of the time was observed in people with asthma (19.1\%), chronic bronchitis (29.7\%), or COPD (30.9\%) compared to the general population (GP: 12.8\%). Fewer patients with these conditions reported finding their sleep "refreshing" most of the time (A: 50.7\%; CB: 42.1\%; COPD: $45.1 \%$ ) compared to those without these ailments $(62.3 \%)$. A difference was also observed in regard to difficulty in staying awake most of the time during the day (A: $8.3 \%$; $\mathrm{CB}: 10.5 \%$; COPD: $11.0 \%$; GP: $5.7 \%)$ and in the degree to which chronic fatigue was reported (A: $1.7 \%$; BC: 3.2\%; COPD: 5.2\%; GP: 0.8\%). Canadians with asthma and COPD report more sleep disturbance and chronic fatigue than healthy people.

Centre de recherche de l'Institut universitaire de cardiologie et de pneumologie de Québec, Canada

\section{Deliverables}

Eventually, this study will be published in a journal and will be presented at both national and international conferences.

\section{Relevance}

This study will help optimize treatment in respiratory diseases. A better knowledge base will result in better treatment. Asking questions about quality of sleep will provide physicians with a better understanding of their patient. This type of question will indicate to them how the disease impacts patient's lives.

Published: 26 November 2010

doi:10.1186/1710-1492-6-S3-P14

Cite this article as: Cormiers and Boulet: Sleep disturbances in a

Canadian population with asthma or chronic obstructive pulmonary

disease (COPD). Allergy, Asthma \& Clinical Immunology 2010 6(Suppl 3):P14.

Submit your next manuscript to BioMed Central and take full advantage of:

- Convenient online submission

- Thorough peer review

- No space constraints or color figure charges

- Immediate publication on acceptance

- Inclusion in PubMed, CAS, Scopus and Google Scholar

- Research which is freely available for redistribution 